\title{
A pajzsmirigygöbök genetikai vizsgálata újgenerációs szekvenáláson alapuló platformon kifejlesztett génpanel segítségével
}

\author{
Kocsis-Deák Barbara ${ }^{1}$ - Balla Bernadett dr. ${ }^{1,2}$ - Árvai Kristóf ${ }^{2}$ \\ Tobiás Bálint dr. ${ }^{1,2}$. Győri Gabriella dr. ${ }^{3}$. Járay Balázs dr. ${ }^{4}$ \\ Székely Eszter dr. ${ }^{4}$. Podani János ${ }^{5}$. Kósa János dr. ${ }^{1,2}$ - Lakatos Péter dr. ${ }^{1,2}$ \\ 'Semmelweis Egyetem, Általános Orvostudományi Kar, I. Belgyógyászati Klinika, Budapest \\ ${ }_{2}^{2}$ PentaCore Laboratórium, Budapest \\ ${ }^{3}$ Semmelweis Egyetem, Általános Orvostudományi Kar, Radiológiai Klinika, Budapest \\ ${ }^{4}$ Semmelweis Egyetem, Általános Orvostudományi Kar, II. Patológiai Intézet, Budapest \\ ${ }^{5}$ Eötvös Loránd Tudományegyetem, Biológiai Intézet, Budapest
}

\begin{abstract}
Bevezetés: Vékonytű-biopsziás pajzsmirigygöbminták 25\%-ánál bizonytalan citológiai eredményt kapunk. A göbök genetikai vizsgálata hozzájárulhat a pontos diagnózishoz.

Célkitüzés: Európában az első és a legtöbb, 23 releváns pajzsmirigyonkogént (568 mutációval) tartalmazó génpanel kialakítása.

Módszer: A biopsziás mintákból izolált DNS vizsgálata Ion Torrent újgenerációs szekvenálással történt.

Eredmények: Módszerünk validációját tumorszövetmintákon végeztük, ennek során 127, a pajzsmirigydaganatokban eddig nem ismert eltéréseket azonosítottunk. Az $A X I N 1$ a legpolimorfabb génnek, míg a $B R A F$ c.1799T>A (V600E) a leggyakrabban azonosított mutációnak bizonyult. A vékonytü-biopsziás mintáinkban 36-féle, klinikailag releváns variánst detektáltunk, melyek 75\%-a az irodalomban még nincs leírva. A citológiailag malignus nyolc mintánk közül hatban, a bizonytalan citológiájú tizennégy mintánk közül nyolcban, míg a citológiailag benignus huszonnyolc mintánk közül húszban azonosítottunk patogén variánst valamely driver génben ( $B R A F$ c.1799T>A, NRAS c.181C >A). Következtetés: Olyan validált, megbízhatóan múködő újgenerációs szekvenáláson alapú módszert fejlesztettünk ki, amely nagy pozitív prediktív értékkel (89\%) és szenzitivitással (79\%) képes a pajzsmirigy rosszindulatú elváltozásainak korai felismerésére.
\end{abstract}

Orv Hetil. 2019; 160(36): 1417-1425.

Kulcsszavak: pajzsmirigydaganatok, pajzsmirigygöbök genetikai vizsgálata, újgenerációs szekvenálás, génpanel

\section{Genetic testing of thyroid nodules using a gene panel developed on a new generation sequencing platform}

Introduction: Twenty-five percent of fine-needle aspiration biopsy samples of thyroid nodules produce indeterminate cytological results. Genetic testing of nodules can contribute to accurate diagnosis.

Aim: Developing the first gene panel in Europe utilizing the 23 most relevant thyroid oncogenes with 568 mutations.

Method: Examination of the isolated DNA from biopsy samples by Ion Torrent new generation sequencing.

Results: The validation of our method was performed on tumor tissue samples, in which 127 genetic variations were identified, yet unknown in thyroid tumors. AXIN1 was the most polymorphic gene, while $B R A F$ c.1799T $>$ A (V600E) was the most frequently identified mutation. We detected 36 clinically relevant variants, $75 \%$ of which have not been described in the literature. Six of our 8 cytologically malignant and 8 of our 14 indeterminate as well as 20 of our 28 cytologically benign samples were identified as containing pathologic variants in a driver gene $(B R A F$ c. $1799 \mathrm{~T}>\mathrm{A}, \mathrm{NR} A S$ c.181C $>\mathrm{A})$. 
Conclusion: We have developed a validated, reliable new generation sequencing-based method with high positive predictive value $(89 \%)$ and sensitivity $(79 \%)$, suitable for the early detection of malignant lesions in the thyroid.

Keywords: thyroid tumors, genetic testing of thyroid nodules, new generation sequencing, gene panel

Kocsis-Deák B, Balla B, Árvai K, Tobiás B, Győri G, Járay B, Székely E, Podani J, Kósa J, Lakatos P. [Genetic testing of thyroid nodules using a gene panel developed on a new generation sequencing platform]. Orv Hetil. 2019; 160(36): 1417-1425.

(Beérkezett: 2019. március 27.; elfogadva: 2019. április 25.)

\begin{abstract}
Rövidítések
ATC $=$ (anaplastic thyroid cancer $)$ anaplasticus pajzsmirigy-carcinoma; $\mathrm{COSMIC}=($ Catalogue of Somatic Mutations in Cancer) A rákos szomatikus mutációk katalógusa; $\mathrm{CT}=$ (computed tomography) számítógépes tomográfia; DNS = dezoxiribonukleinsav; DTC $=$ (differentiated thyroid cancer $)$ differenciált pajzsmirigy-carcinoma; ETT-TUKEB = Egészségügyi Tudományos Tanács, Tudományos és Kutatásetikai Bizottság; FNAB = (fine-needle aspiration biopsy) vékonytü-aspirációs biopszia; FTC $=$ (follicular thyroid carcinoma) follicularis pajzsmirigycarcinoma; ISP $=$ Ion Sphere Particle $;$ MAPK $=$ (mitogen-activated protein kinase) mitogén által aktivált proteinkináz; MEN2 = (multiple endocrine neoplasia type 2) multiplex endokrin neoplasia- 2 miRNS $=$ mikro-RNS $; \mathrm{MNV}=$ (multi-nuc leotide variant) többszörös nukleotidvariáns; $\mathrm{MR}=$ (magnetic resonance) mágneses rezonancia; $\mathrm{mRNS}=($ messenger RNA $)$ hírvivő RNS; MTC = (medullary thyroid cancer $)$ medullaris pajzsmirigyrák; NGS = (next generation sequencing $)$ újgenerációs szekvenálás; NPV = (negative predictive value) negatív prediktív érték; PBS = (phosphate-buffered saline) foszfátpufferes sóoldat; $\mathrm{PCR}=($ polymerase chain reaction $)$ polimerázláncreakció; PI3K/AKT = foszfatidil-inozitol-3-kináz/AKT; $\mathrm{PPV}=$ (positive predictive value) pozitív prediktív érték; PTC $=$ (papillary thyroid carcinoma) papillaris pajzsmirigy-carcino$\mathrm{ma}$; RNS = ribonukleinsav; SNV = (single-nucleotide variant $)$ egyedi nukleotidvariáns; $\mathrm{UH}=$ ultrahang
\end{abstract}

Az elmúlt évtizedekben a pajzsmirigytumorok a leggyakoribb endokrin daganattá váltak, és világszerte folyamatosan emelkedő incidenciát mutatnak [1]. Tapintható göbök a pajzsmirigyek 4-7\%-ában fordulnak elő a hazai populációban [2], míg a nem tapintható és ultrahanggal nem látható göbök jóval gyakoribbak. Ezeket az elváltozásokat sokszor egyéb indikációjú képalkotó vizsgálatok elvégzésekor azonosítják, mint például a nyaki erek Doppler-vizsgálata, illetve a nyaki CT/MR során. Így a hazai lakosság 20-50\%-ában fedezhetnek fel göböket, vizsgálati módszertől függően [3], melyek kb. 2-10\%ában daganat alakul ki.

A rosszindulatú elváltozások többségét ún. hideg, azaz radioaktív jódot nem felhalmozó göbökben azonosítják. A ma alkalmazott pajzsmirigyvizsgálati módszerek közül rutinszerúen alkalmazzák az ultrahang (UH)-vizsgálatot. Ennek segítségével olyan jellegzetességek fedezhetôk fel, amelyek segítenek következtetni a göb esetleges malignus tulajdonságaira. Ennek tisztázása azonban további vizsgálatokat igényel. Vékonytú-aspirációs biopszia (fine-needle aspiration biopsy $=$ FNAB) segítségével történhet mintavétel a malignitásra gyanús göbökből. A mintákat a citológiai kiértékelés folyamán hatféle kategóriába sorolják a Bethesda-rendszer alapján [4]: Cl - értékelhetetlen minta, C2 - benignus elváltozás, C3 - nem meghatározható, atípusos minta, $\mathrm{C} 4$ - follicularis neoplasia vagy annak gyanúja, C5 - malignitásra gyanús és C6 - egyértelmúen rosszindulatú daganat. A kinyert sejtek vizsgálata az esetek kb. 25\%-ában bizonytalan eredményt ad. A minták 3-20\%-a a C3-as kategóriába sorolható, ahol a malignitási kockázat 5-15\% körül mozog [5]; ilyen esetekben a ma alkalmazott megoldás a későbbi ismételt mintavétel, illetve ha szükséges, akkor mútéti beavatkozás.

Az utóbbi évtizedben további - az FNAB-alapú citológiát kiegészítő - diagnosztikus módszerek után kutattak, melyek csökkenthetnék ezen bizonytalan kategóriába kerülő minták számát. Több tanulmányban is felvetették a göbök genetikai vizsgálatának lehetőségét, melynek segítségével mélyebb betekintést kaphatunk ezen elváltozások molekuláris hátterébe, ami hozzájárulhat a pontos diagnózishoz. A pajzsmirigyrákban megismert számos genetikai elváltozás hatékonyan alkalmazható a molekuláris diagnosztika területén. Világszerte a papillaris pajzsmirigy-carcinoma (PTC) előfordulása a leggyakoribb a pajzsmirigytumorok között, a magyar populációban is ez a típus fordul elő $60-85 \%$-ban [6].

Egy malignitásra gyanús göb komplex genetikai háttérrel rendelkező megbetegedés, melynek vizsgálatára ma az újgenerációs szekvenáláson (NGS) alapuló platformok a legalkalmasabbak. Ezek közös tulajdonsága, hogy képesek párhuzamosan, egy időben több millió DNS-szál pontos leolvasására, tehát nagy az áteresztőképességük; sokkal gyorsabbak, rövidebb idő alatt képesek eredményt adni, és mindezt jóval kedvezőbb áron képesek elvégezni, mint a hagyományos Sanger-szekvenálás. Az NGS-platformok által hatalmas mennyiségú genetikai információhoz jutunk, melyeket bioinformatikai szoftverekkel és online adatbázisokkal tudunk elemezni. További előnye a Sanger-szekvenálással szemben, hogy nem csupán egy gén célzott hot spotjait képes azonosítani, hanem több tíz vagy száz gén teljes bázissorendjének leolvasására képes. 
E jellemzők alapozták meg az általunk kifejlesztett génpanel bevezetését és klinikai validálását, mely egy időben vizsgálja számos, pajzsmirigyrákban ismert gén szomatikus eltérését, Ion Torrent platformon. Az általunk tervezett multiplex PCR-alapú AmpliSeq hot spot panel 23 rákgént ( $A K T 1, A P C, A X I N 1, B R A F, C 16 o r f 3$, CTNNBI, DICERI, EIFIAX, GNAS, HRAS, IDHI, KRAS, LPAR4, MET, NRAS, PIK3CA, PTEN, RET, SMAD4, TERT, TP53, TSHR, VHL) és azon belül 568 ismert onkogén mutációt tartalmaz. Módszerünk kidolgozása során alapvető célunk volt egy kiterjesztett panel létrehozása, mely nemcsak a leggyakrabban mutált géneket (például BRAF, RAS) tartalmazza, hanem több olyan gént is, amelynek mutációja ritkábban fordul elő bizonyos pajzsmirigytumorokban. Végső célunk egy olyan diszkriminatív géncsoport, illetve mutációs mintázat meghatározása, amely hozzájárulhat a pajzsmirigygöbök malignizációjának előrejelzésére.

\section{Módszer}

\section{Vizsgált minták}

A vizsgálat beállítását és validálását kétféle mintacsoporton végeztük:

1. Igazoltan PTC-s páciensekből származó tumoros és ép/egészséges pajzsmirigyszövet-minták, melyeket operáció során gyüjtöttünk.

2. FNAB segítségével vett biopsziás minták.

\section{Mütéti mintákon végzett validálási vizsgálat}

Vizsgálatsorozatunk első felében PTC-s szövetből és ugyanazon beteg normál-pajzsmirigyszövetéből származó izolált DNS-t elemeztünk. Ezen mintákat 40 betegtől gyüjtöttük be 2010 és 2016 között, a Semmelweis Egyetem Sebészeti Klinikáján. Összesen 67 darab pajzsmirigymintát vizsgáltunk meg: 39 PTC-s és 28, szövettanilag tumormentes pajzsmirigyszövetet. Ezek közül 27 minta volt párban (vagyis a PTC és az ép minta is ugyanabból a betegből származott), míg 12 csak PTC-s és 1 ép szövetból származott. A vizsgálatot a Nemzeti Kutatási Etikai Bizottság hagyta jóvá, és minden beteg írásban beleegyezett a vizsgálat elvégzésébe (ETT-TUKEB 11600/2010-1018EKU).

A begyújtött szövetmintákat $-80{ }^{\circ} \mathrm{C}$-on tároltuk feldolgozásig, majd PBS-ben homogenizáltuk Fisher Scientific PowerGen szövetdarálóval (Fisher Scientific GmbH, Schwerte, Németország), és genomiális DNS-t izoláltunk Roche High Pure PCR Template Preparation Kit (Roche, Indianapolis, IN, Amerikai Egyesült Államok [USA]) segítségével, a gyártó előírása szerint. Az izolált DNS koncentrációját a Qubit dsDNA HS assay kit segítségével (Thermo Fisher, Waltham, MA, USA), míg a DNS minőségét NanoDrop spektrofotométerrel (NanoDrop Technologies, Montchanin, DE, USA) 260/280 nm-en határoztuk meg.

\section{Biopsziás mintákon végzett vizsgálat}

Vizsgálatsorozatunk második felében pajzsmirigyFNAB-mintákból izolált DNS-t elemeztünk. Összesen 77 páciens ultrahanggal gyanúsnak ítélt pajzsmirigygöbéből történt mintavétel, melyeket speciális tartósítóoldatban, $4{ }^{\circ} \mathrm{C}$-on tároltunk. A mintavételek 2017 és 2018 között, a Semmelweis Egyetem Sebészeti Klinikáján, illetve az Istenhegyi Magánklinikán történtek. A vizsgálatot a Nemzeti Kutatási Etikai Bizottság hagyta jóvá, és minden beteg írásban beleegyezett a vizsgálat elvégzésébe (ETT-TUKEB 1160-0/2010-1018EKU).

A biopsziás mintákból a DNS-izolálás a QIAamp DNA Blood Mini Kittel történt, a gyártó elóírása szerint, majd az izolált DNS koncentrációját Qubit dsDNA HS assay kit segítségével, míg a DNS minőségét NanoDrop spektrofotométerrel 260/280 nm-en határoztuk meg.

\section{Szekvenálás és adatelemzés}

A DNS-könyvtárakat az Ion AmpliSeq Library Kit 2.0 (Thermo Fisher, Waltham, MA, USA) alkalmazásával készítettük el: a multiplex primer poolokhoz $10 \mathrm{ng}$ genomiális DNS-t adtunk, majd PCR-rel felamplifikáltuk ( 2 perc $99^{\circ} \mathrm{C}$-on, 15 másodperc $99^{\circ} \mathrm{C}$-on és 4 perc $60{ }^{\circ} \mathrm{C}$-on [21 ciklus], végül $10{ }^{\circ} \mathrm{C}$-on tartva). A PCR után $\mathrm{FuPa}$ reagens segítségével a primereket részben visszaemésztettük, ezután szekvenálóadaptereket és egyedi bárkódokat ligáltunk az amplikonokhoz. A könyvtárakat kitisztítottuk Agencourt AMPure XP reagenssel (Beckman Coulter, Sacramento, CA, USA), majd a végleges könyvtárak koncentrációját Ion Library TaqMan Quantitation Kit (Thermo Fisher, Waltham, MA, USA) segítségével határoztuk meg. A templát előkészítését Ion PGM ${ }^{\mathrm{TM}} \mathrm{Hi}-\mathrm{Q}$ View OT2 Kittel (Thermo Fisher, Waltham, MA, USA) végeztük egy félautomata Ion OneTouch 2 készüléken, emulziós PCR-módszerrel; ilyenkor a DNS-fragmentumokat mikrométer nagyságrendű szekvenálógyöngyök felületén amplifikáljuk, víz-olaj emulzióban. Ezután Ion OneTouch ES (Thermo Fisher, Waltham, MA, USA) segítségével a templátot nem tartalmazó gyöngyöket eltávolítottuk. Szekvenálóprimert és -polimerázt adtunk a templátot tartalmazó gyöngyökhöz, majd az így előkészített Ion Sphere Particle (ISP-) gyöngyöket egy Ion 314v2 BC szekvenálóchipbe töltöttük, és elindítottuk a szekvenálást Ion PGM $^{\mathrm{TM}} \mathrm{Hi}-\mathrm{Q}^{\mathrm{TM}}$ View Sequencing Kit (Thermo Fisher, Waltham, MA, USA) segítségével.

Az Ion Torrent szekvenátor futásából származó adatokat a platformspecifikus Torrent Suite v 5.0.4 szoftver (Thermo Fisher, Waltham, MA, USA) segítségével kiértékeltük. Az eredményes elemzéshez és a variánsok azonosításához megfelelő lefedettség szükséges. Az általunk vizsgált mutációknál minimum $10 \times$-es volt a lefedettség, és akár 5\%-os allélgyakoriságot is detektáltunk. Átlagos lefedettségünk minden esetben meghaladta a 400x-t. A népességben 1\%-nál nagyobb gyakorisággal előforduló változatokat a további elemzésből kiszűrtük. A szek- 
venálás során kapott leolvasásokat a referenciagenomhoz (hg19) illesztettük a TMAP (https://github.com/iontorrent/TMAP) algoritmus segítségével, majd a variáns hívót úgy állítottuk be, hogy a szomatikus variánsokat megtalálja az adott régiókban. Ion Reporter 5.0-t (Thermo Fisher, Waltham, MA, USA) használtunk a variánsok jelölésére.

\section{Eredmények}

\section{A mütéti mintákon végzett validálási vizsgálat eredményei}

\section{Páciens/minta adatok}

Validálási vizsgálatunkba 31 női (átlagéletkor: 49,5 év) és 9 férfi (átlagéletkor: 55,1 év) pácienstől származó pajzsmirigyszöveti minta került bevonásra. A vizsgált 39 PTC-minta 7 különböző variánsát azonosítottuk. A legtöbb esetben 24 klasszikus PTC, illetve 4 follicularis variáns, 3 enkapszulált, 3 Hürthle-sejtes, 1 oncocyter, 1 multifokális és 3 microcarcinoma fordult elő. A tumoros elváltozás három típusnál (klasszikus, enkapszulált, multifokális variáns) jelent meg mindkét lebenyben. Az átlagos tumorátmérőt megvizsgálva a legnagyobb daganatméretet a follicularis variánsok esetében tapasztaltuk (átlagos tumorátmérő: 18,8 mm). Mintáink ezen jellemzőit az 1. táblázatban foglaltuk össze.

Az operáció során a páciensek pajzsmirigyszövetéből vett mintákon szövettani vizsgálat történt, melynek eredménye alapján különítettük el a tumoros, illetve az ugyanazon páciensekből származó egészséges/tumormentes mintákat. Ezek alapján kerültek be a minták ge-

1. táblázat A pácienseinkben azonosított 39 PTC-s minta altípusba sorolása és az ezen daganattípusokra jellemző tulajdonságok

\begin{tabular}{lccc}
\hline $\begin{array}{l}\text { PTC-minták } \\
(\mathrm{n}=39)\end{array}$ & Nö/Férfi (n) & $\begin{array}{c}\text { Lebenyek } \\
\text { érintettsége } \\
\text { egy/ } \\
\text { mindkettó }(\mathrm{n})\end{array}$ & $\begin{array}{c}\text { Átlagos } \\
\text { tumorátméró } \\
(\mathrm{mm})\end{array}$ \\
\hline $\begin{array}{l}\text { Klasszikus PTC } \\
(\mathrm{n}=24)\end{array}$ & $17 / 1$ & $18 / 6$ & 14,8 \\
$\begin{array}{l}\text { Follicularis variáns } \\
(\mathrm{n}=4)\end{array}$ & $3 / 1$ & $4 / 0$ & 18,8 \\
$\begin{array}{l}\text { Enkapszulált variáns } \\
(\mathrm{n}=3)\end{array}$ & $3 / 0$ & $1 / 2$ & 14,3 \\
$\begin{array}{l}\text { Hürthle-sejtes variáns } \\
(\mathrm{n}=3)\end{array}$ & $3 / 0$ & $3 / 0$ & 16,3 \\
$\begin{array}{l}\text { Oncocyter variáns } \\
(\mathrm{n}=1)\end{array}$ & $1 / 0$ & $1 / 0$ & $\mathrm{~N} / \mathrm{A}$ \\
$\begin{array}{l}\text { Multifokális variáns } \\
(\mathrm{n}=1)\end{array}$ & $1 / 0$ & $0 / 1$ & $\mathrm{~N} / \mathrm{A}$ \\
$\begin{array}{l}\text { Microcarcinoma } \\
(\mathrm{n}=3)\end{array}$ & $3 / 0$ & $3 / 0$ & 3,3 \\
\hline
\end{tabular}

$\mathrm{n}=$ darabszám $; \mathrm{N} / \mathrm{A}=$ nincs adat $; \mathrm{PTC}=$ papillaris pajzsmirigy-carcinoma netikai vizsgálatunkba, így kialakítva a két vizsgálati csoportot: 1. PTC-s tumorminta és 2. tumormentes, egészséges minta.

\section{A genetikai vizsgálat eredményei}

A szekvenálás végén kapott adatok megbízhatóságát futásonként ellenőriznünk kellett, hiszen ezen paraméterek (például átlagos leolvasási szám, átlagos lefedettség) megfelelő értéke a variánsok megbízható azonosításához szükséges. A kapott NGS-eredményeknél mintánként 143211 read volt az átlagos leolvasási szám. Az átlagos lefedettség 642×-esnek, míg az átlagos $1 \times$-es célszekvencia-lefedettség 98,2\% körül adódott. Az általunk vizsgált pajzsmirigyminták minden esetben megfelelő értékekkel rendelkeztek, így a kapott eltéréseket megbízhatónak ítéltük.

A 67 pajzsmirigyszövet-mintában összesen 177 aminosavcserével járó variánst találtunk, ezek közül 143 single-nucleotide variánst (SNV; 142 misszenszt és 3 nonszenszt), 31 INDEL-t (27 insertiót, 3 deletiót és 1 frameshift deletiót) és 1 misszensz multiple nucleotide variánst (MNV) azonosítottunk. Ezek közül 127 olyan eltérést találtunk, melyet eddig még nem írtak le pajzsmirigydaganatokban, míg a maradék 50 mutációt korábban már azonosították (többségüket pajzsmirigyrákokkal, míg néhányat egyéb, nem pajzsmirigyrákos megbetegedésekkel [például mellrák, hasnyálmirigyrák, vastagbélrák] összefüggésben).

\section{a) PTC-szövetben talált mutációk}

A bizonyítottan PTC-s szövetmintákban a 23 vizsgált génből 20 esetén találtunk legalább egy eltérést, összesen 102 szomatikus mutációt detektáltunk bennük. Az $A X I N 1$ mutatkozott a legpolimorfabb génnek, 16 variánssal. Ezt követte a $P I K 3 C A-$, az $A P C$-és a TSHR-gén, melyeknek 15, 14, illetve 13 variánsát azonosítottuk. A leggyakrabban azonosított mutáció a jól ismert $B R A F$ c.1799T >A (V600E) volt, mely 14 PTC-szöveti mintában fordult elő. Emellett további 2 mutáció fordult elő gyakran: 5 esetben TSHR c.1373T>C, míg 4 esetben APC c.636_637insAA frameshift mutáció.

A PTC klasszikus altípusában a V600E mutáció mellett egyéb $B R A F$-mutációk is megtalálhatók, míg a PTCvariánsokban csak a V600E van jelen. A klasszikus típusban észleltünk egy nem bizonyítottan, de nagy valószínúséggel patogén 1795A>G (T599A) variánst. Kimutattuk, hogy a V600E-pozitivitás mellett egyéb géneket érintő mutációk kevésbé fordultak elő adott PTCmintában, mint azon tumoros mintákban, ahol a V600E mutáció nem volt jelen.

Egy tumoros mintában átlagosan 5,74 mutációt találtunk; egy PTC-mintában a legtöbb mutációszám 19 volt, míg két esetben egyetlen szomatikus mutációt sem tudtunk azonosítani a vizsgált génekben.

Tumoros mintáinkban a 23 gén közül 3 génben egy mutációt sem találtunk; TERT promóter elváltozásokat 
nem detektáltunk; illetve a $G N A S$ - és a $K R A S$-génben sem találtunk eltérést.

\section{b) Tumormentes, egészséges szöpetben talált mutációk}

A szövettanilag egészséges mintákban összesen 52 szomatikus eltérést találtunk, 15 génben. Itt is az $A X I N 1$ gén volt a legpolimorfabb, ennek mutációs mintázata azonban eltért a tumormintákban leírtakétól. Összesen 8 génben egyetlen mutációt sem azonosítottunk ( $A K T 1$, BRAF, GNAS, HRAS, KRAS, NRAS, TERT, VHL).

\section{A FNAB-mintákon végzett vizsgálat eredményei}

\section{Páciens/minta adatok}

FNAB segítségével összesen 77 páciens malignitásra gyanús pajzsmirigygöbéből történt mintavétel. A mintákból izolált DNS koncentrációja kritikus az NGS-vizsgálat sikerességét tekintve. A túl alacsony DNS-koncentrációjú mintákat sikertelennek ítéltük, és kizártuk a további vizsgálatból. Így összesen 51 sikeres mintánk volt, melyek 41 női (átlagéletkor: 53 év) és 10 férfi (átlagéletkor: 45 év) pácienstől származtak.

A FNAB-minták közül a citológiai kiértékelés 8 esetben adott malignus eredményt (2. táblázat). Negatív citológiai lelet keletkezett 28 páciensnél (ez eseteink 55\%-a), tehát ezen mintákban malignitásra utaló elváltozás nem volt. Tizennégy esetben a minták a malignus gyanús kategóriák egyikébe estek. Míg egy esetben nincs információnk a citológiai eredményről a kenet sejtmentessége miatt, azonban az NGS-vizsgálathoz elkülönített mintából elegendő volt a DNS-mennyiség, így genetikai eredmény készülhetett.

\section{A genetikai vizsgálat eredményei}

A kapott NGS-eredményeknél mintánként 243955 read volt az átlagos leolvasási szám. Az átlagos lefedettség $4312 \times$-es, míg az átlagos $10 \times$-es célszekvencia-lefedettség $87 \%$ volt. Az általunk vizsgált pajzsmirigyminták minden esetben megfelelő értékekkel rendelkeztek, így a kapott eltéréseket megbízhatónak ítéltük.

A vizsgált 51 mintából 35-ben találtunk klinikailag releváns genetikai eltérést. Összesen 36-féle aminosavcserével járó variánst azonosítottunk (24 SNV [24 misz-

2. táblázat |A citológiai vizsgálat eredményei az 51 FNAB-minta esetében

\begin{tabular}{lcc}
\hline & Mintaszám (n) & Nő/Férfi (n) \\
\hline Pozitív citológiai lelet & 8 & $6 / 2$ \\
Negatív citológiai lelet & 28 & $25 / 3$ \\
Gyanús citológiai lelet & 14 & $9 / 5$ \\
N/A (Sejtmentes kenet) & 1 & $1 / 0$ \\
\hline Összesen & 51 & 51 \\
\hline
\end{tabular}

FNAB = vékonytû-aspirációs biopszia; $\mathrm{n}=$ darabszám; $\mathrm{N} / \mathrm{A}=$ nincs adat szensz], 7 INDEL [1 insertio és 6 deletio], 2 splice site variáns, 1 intronikus régióba eső mutáció, $2 \mathrm{MNV}$ ) (3. táblázat). Ezek közül 27 olyan eltérést találtunk, amelyet eddig még nem írtak le pajzsmirigydaganatokban, míg 9-et már azonosítottak korábban. Ezek többségét pajzsmirigyrákokban ismerték fel, míg néhányat nem pajzsmirigy-daganatos megbetegedésekkel (például hasnyálmirigyrák, vastagbélrák stb.) is összefüggésbe hozták.

A 8 pozitív citológiai/malignus megjelölésú FNABmintánk közül 6-ban különböző patogén eltéréseket azonosítottunk ( $B R A F$ c.1799T >A, LPAR 4 c.137A > G, $A P C$ c.1758A>C, $A X I N 1$ c.120_122delCAGinsAGC, SMAD4 c.1569C>G, TSHR c.749_753delAGGAA). A citológia alapján negatív besorolást kapó, a vizsgálat pillanatában malignitásra utaló jeleket nem mutató 28 mintánk közül 20 esetben találtunk genetikai elváltozást, mely kockázatot jelenthet pajzsmirigydaganat kialakulására; a már ismert eltérések közül egy-egy mintában megtaláltuk a $E I F I A X$ c.338-1G >C, a $H R A S$ c.181C >A, a PTEN c.634+2T>G, a TSHR c.1887G $>\mathrm{T}$ és c.1895C > T mutációkat. A legtöbbször ( 6 mintában) az LPAR 4 c.137A>G mutáció fordult elő, mely irodalmi adatok alapján a PTC malignus állapotával áll kapcsolatban [7]. További 8 esetben, ahol a citológiai eredmény nem mutatott ki malignus elváltozást, nem detektáltunk eltérést a vizsgált génekben. A 14 malignitásra gyanús (bizonytalan) citológiai eredményt mutató mintánál 6 esetben nem találtunk genetikai eltérést, míg 8-ban detektáltunk valamilyen patogén variánst. Ezek közül a jól ismert $B R A F$ c.1799T $>\mathrm{A}$ és az NRAS-gén c.181C>A variánsát fedeztük fel egy-egy mintában, míg a többi páciensnél az APC, AXIN1, LPAR4, SMAD4, TERT és $V H L$ génekben azonosítottunk mutációkat. Annál az egy páciensnél, akinél a citológiai értékeléshez sejtmentes kenet készült, a genetikai vizsgálatra párhuzamosan félretett mintából sikerült kimutatnunk egy LPAR4 c.137A>G génhibát. Az eredményeket a 4. táblázatban foglaltuk össze.

A megvizsgált mintáinkban összesen 36-féle, klinikailag releváns mutációt azonosítottunk, 15 génben. A legpolimorfabb gén az $A X I N 1$ volt, 6 különböző variánssal. A citológiai eredményekkel összevetve e 6 variáns közül egyet (c.120_122delCAGinsAGC) pozitív, hármat (c.1326delC, c.2392A>G és c.476A>G) malignitásra gyanús göbökben fedeztünk fel, míg a c.1887_1891delCCAGA és c.2155A>G variánsait negatív citológiájú mintákban. Az $A X I N 1$ után 5 variánssal a TSHR-gén (citológiai eredmények: 1 pozitív, 4 negatív) fordult elő a legtöbbször. A leggyakoribb mutációnk az LPAR 4 c.137A>G (p.Tyr46Cys) volt, amely egy aminosavcserével járó misszensz mutáció, melyet 11 mintánkban azonosítottunk. Az LPAR 4 c.137A>G eltérést hordozó minták többsége negatív citológiai eredményt mutatott (11/6 eset), míg 2 esetben pozitív, másik 2 esetben malignitásra gyanús kategóriába sorolták ezeket, 
3. táblázat A 36-féle mutáció, melyet FNAB-pajzsmirigymintákban azonosítottunk. Feltüntettük a mutációk típusát és COSMIC-azonosítójukat is, amennyiben az adott variánst már leírták a szakirodalomban, illetve az utolsó oszlopban leírtuk, hogy a citológiai kiértékelés során milyen besorolást kapott az adott minta, amelyben az adott variánst megtaláltuk

\begin{tabular}{|c|c|c|c|c|}
\hline Gén & Mutáció & A mutáció típusa & COSMIC-azonosító & $\begin{array}{l}\text { Milyen citológiai mintában } \\
\text { találtuk? }\end{array}$ \\
\hline$A P C$ & c. $1758 \mathrm{~A}>\mathrm{C}$ & Misszensz & - & $\mathrm{P}$ \\
\hline$A P C$ & c. $2788 \mathrm{~A}>\mathrm{C}$ & Misszensz & - & GY \\
\hline$A P C$ & c. $4343 \mathrm{C}<\mathrm{G}$ & Misszensz & - & $2 \mathrm{~N}$ \\
\hline$A P C$ & c. $4679 \mathrm{~A}>\mathrm{T}$ & Misszensz & - & $\mathrm{N}$ \\
\hline$A X I N I$ & c.120_122delCAGinsAGC & $\mathrm{MNV}$ & - & $\mathrm{P}$ \\
\hline$A X I N I$ & c.1326delC & Deletio & - & GY \\
\hline$A X I N I$ & c.1887_1891delCCAGA & Deletio & - & $\mathrm{N}$ \\
\hline AXINI & c. $2155 \mathrm{~A}>\mathrm{G}$ & Misszensz & - & $\mathrm{N}$ \\
\hline$A X I N 1$ & c. $2392 \mathrm{~A}>\mathrm{G}$ & Misszensz & - & GY \\
\hline$A X I N I$ & c. $476 \mathrm{~A}>\mathrm{G}$ & Misszensz & - & GY \\
\hline$B R A F$ & c. $1799 \mathrm{~T}>\mathrm{A}$ & Misszensz & COSM476 & $4 \mathrm{P}, \mathrm{GY}$ \\
\hline EIFIAX & c. $17 \mathrm{G}>\mathrm{T}$ & Misszensz & - & $\mathrm{N}$ \\
\hline EIFIAX & c. $338-1 \mathrm{G}>\mathrm{C}$ & Splice site & COSM3372212 & $\mathrm{N}$ \\
\hline EIFIAX & c.51_52insA & Insertio & - & $2 \mathrm{~N}$ \\
\hline EIFIAX & c.75delA & Deletio & - & $\mathrm{N}$ \\
\hline$H R A S$ & c. $181 \mathrm{C}>\mathrm{A}$ & Misszensz & COSM496 & $\mathrm{N}$ \\
\hline$I D H I$ & c. $142 \mathrm{~A}>\mathrm{G}$ & Misszensz & - & $\mathrm{N}$ \\
\hline LPAR4 & c. $137 \mathrm{~A}>\mathrm{G}$ & Misszensz & - & $2 \mathrm{P}, 6 \mathrm{~N}, 2 \mathrm{GY}, 1 \mathrm{~N} / \mathrm{A}$ \\
\hline LPAR4 & c. $824 \mathrm{~T}>\mathrm{C}$ & Misszensz & - & $\mathrm{N}$ \\
\hline$M E T$ & c. $4079 \mathrm{C}>\mathrm{T}$ & Misszensz & - & $\mathrm{N}$ \\
\hline NRAS & c. $181 \mathrm{C}>\mathrm{A}$ & Misszensz & COSM580 & GY \\
\hline PIK $3 C A$ & c. $1034 \mathrm{~A}<\mathrm{G}$ & Misszensz & - & $\mathrm{N}$ \\
\hline PTEN & c. $398 \mathrm{~T}>\mathrm{A}$ & Misszensz & - & $\mathrm{N}$ \\
\hline PTEN & c. $409 \mathrm{G}>\mathrm{C}$ & Misszensz & - & $\mathrm{N}$ \\
\hline PTEN & c.411_413delATA & Deletio & - & $\mathrm{N}$ \\
\hline PTEN & c. $634+2 \mathrm{~T}>\mathrm{G}$ & Splice site & COSM1968251 & $\mathrm{N}$ \\
\hline SMAD4 & c. $1561 \mathrm{~A}>\mathrm{G}$ & Misszensz & - & GY \\
\hline SMAD4 & c. $1569 \mathrm{C}>\mathrm{G}$ & Misszensz & COSM14115 & $\mathrm{P}$ \\
\hline SMAD4 & c. $919 \mathrm{G}>\mathrm{A}$ & Misszensz & - & $\mathrm{N}$ \\
\hline TERT & c. $-245 \mathrm{~T}>\mathrm{C}$ & Intronikus & - & $\mathrm{N}, \mathrm{GY}$ \\
\hline TSHR & c.1115_1121delACCCCCAinsCCCCCCG & MNV & - & $\mathrm{N}$ \\
\hline TSHR & c. $1887 \mathrm{G}>\mathrm{T}$ & Misszensz & COSM26422 & $\mathrm{N}$ \\
\hline TSHR & c. $1895 \mathrm{C}>\mathrm{T}$ & Misszensz & COSM26418 & $\mathrm{N}$ \\
\hline TSHR & c.745delC & Deletio & - & $\mathrm{N}$ \\
\hline TSHR & c.749_753delAGGAA & Deletio & - & $\mathrm{P}$ \\
\hline$V H L$ & c. $148 \mathrm{G}>\mathrm{A}$ & Misszensz & COSM17999 & GY \\
\hline
\end{tabular}

COSMIC = A rákos szomatikus mutációk katalógusa; FNAB = vékonytü-aspirációs biopszia; Gy = gyanús; bizonytalan kategóriájú minta; Misszensz (missense) mutáció = a DNS bázissorrendjének aminosavcserét eredményező változása; MNV = többszörös nukleotidvariáns; N = negatív, jóindulatú kategóriájú minta; $\mathrm{N} / \mathrm{A}=$ nincs adat, sejtmentes kenet; $\mathrm{P}=$ pozitív, malignus kategóriájú minta

illetve 1 esetben a sejtmentes kenet miatt nincs információnk a citológiai értékelésről.

A detektált mutációk közül kimagasodott a $B R A F$ c.1799T>A (V600E), melyet 5 mintában fedeztünk fel. Ezen minták többsége (4 eset) a citológiai vizsgálat szerint is egyértelmúen malignus eredményt mutatott, míg
1 esetben a bizonytalan kategóriába sorolták. Negatív citológiai mintában nem azonosítottunk BRAF-mutációt.

A kapott eredmények alapján megállapítható, hogy módszerünk nagy pozitív prediktív értékkel $(89 \%)$ és szenzitivitással (79\%) képes megjósolni egy pajzsmirigy- 
4. táblázat $\mid$ A táblázat a vizsgált 51 FNAB-minta citológiai vizsgálat alapján végzett besorolását foglalja össze (1. oszlop), valamint hogy az egyes citológiai kategóriákba sorolt minták genetikai vizsgálata azonosított-e mutációt az analizált génekben

\begin{tabular}{lccc}
\hline & $\begin{array}{c}\text { Mintaszám } \\
(\mathrm{n})\end{array}$ & $\begin{array}{c}\text { Nincs } \\
\text { mutáció }(\mathrm{n})\end{array}$ & $\begin{array}{c}\text { Van mutáció } \\
(\mathrm{n})\end{array}$ \\
\hline Pozitív citológiai lelet & 8 & 2 & 6 \\
Negatív citológiai lelet & 28 & 8 & 20 \\
Gyanús citológiai lelet & 14 & 6 & 8 \\
N/A (Sejtmentes kenet) & 1 & 0 & 1 \\
\hline Összesen & 51 & 16 & 35 \\
\hline
\end{tabular}

FNAB $=$ vékonytü-aspirációs biopszia; $\mathrm{n}=$ darabszám; $\mathrm{N} / \mathrm{A}=$ nincs adat, sejtmentes kenet

göb malignizálódásának kockázatát [8]; a hozzá tartozó specificitási $(86 \%)$ és NPV-értékek $(75 \%)$ is megfelelőek, így nagy segítséget nyújt a malignitásra gyanús, bizonytalan citológiai eredményt kapott pajzsmirigy-elváltozások végleges diagnózisában.

\section{Megbeszélés}

Napjainkban a klinikai gyakorlatban alkalmazott vizsgálati módszerek sokszor későn jelzik a pajzsmirigy tumoros elváltozását, a rosszindulatú daganatok korai felismerése azonban mind a túlélés, mind a terápiamegválasztás szempontjából nagyon fontos. A pajzsmirigyben fellelhető malignus elváltozások mielőbbi felismerésére, a bizonytalan citológiai eredmények kiegészítésére új vizsgálati módszerek szükségesek. Erre ma már egyre inkább módot ad a molekuláris diagnosztika.

PTC-ben a leggyakoribbak a $B R A F$ - és a $R A S$-gén szomatikus mutációi [9]. A PTC-s esetek felében a $B R A F$-gén egyik pontmutációja, a V600E fordul elő. $\mathrm{E}$ mutáció konstitutívan aktiválja a MAPK (mitogén által aktivált proteinkináz) jelátviteli útvonalat, így az érintett sejtek korlátlan növekedését okozza, ami végül daganat kialakulásához vezet. A $R A S$-gének (NRAS, KRAS, $H R A S)$ a MAPK-útvonal mellett hatással vannak a PI3K/AKT (foszfatidil-inozitol-3-kináz/AKT) kaszkádra is. RAS-mutációk a PTC-s esetek 30-45\%-ában fordulnak elő, más típusú (follicularis mintázatú) pajzsmirigytumorok esetében azonban gyakoribbak, például FTC-ben az előfordulásuk $40-75 \%$ is lehet $[10,11]$. E leggyakoribb, nagy hatású gének mellett azonban számos egyéb genetikai eltérés is szerepet játszik a pajzsmirigyrákok patogenezisében [12].

A PTC mellett megkülönböztetünk egyéb pajzsmirigytumor-fajtákat is. A differenciált pajzsmirigyrákok (DTC) csoportjába tartozik a pajzsmirigytumorok $90 \%$-a, melyek a pajzsmirigy folliculusainak epithelsejtjeiből származnak. A PTC mellett idesorolható a follicularis rák (FTC) is, bár ezen esetek előfordulása ritkább, az összes DTC 10-15\%-a. Az FTC-kben leginkább a $\mathrm{PI} 3 \mathrm{~K} / \mathrm{AKT}$ útvonal génmutációit írták le (például 5-15\%-ban PIK3CA-, 10-15\%-ban PTEN-génekben) [5]. A pajzsmirigytumorok másik csoportjába tartoznak a pajzsmirigy follicularis epitheliumának differenciálatlan malignus tumorai, az ún. anaplasticus pajzsmirigy-carcinomák (ATC). Az ATC a legagresszívabb fajtája a pajzsmirigy rosszindulatú daganatainak, mortalitása 100\%-os. Előfordulása szerencsére ritka, az összes pajzsmirigydaganat 1-3\%-át teszi ki. Leírták, hogy ha egy DTC-ben mind a MAPK-, mind a PI3K/AKT útvonal konstitutívan aktív, az ATC kialakulásának nagyobb a valószínűsége. Bizonyos genetikai eltérések megléte ugyanis akár PTC- vagy FTC-állapotból is ATC kialakulásához vezethet. Az ATC-s esetek 25\%-ában a MAPK-útvonalon a BRAF-gén V600E mutációját fedezték fel, míg a PI3K/ AKT útvonal tagjai közül a PIK3CA-és a PTEN-génben találtak eltéréseket a leggyakrabban [13]. A pajzsmirigydaganatok harmadik csoportja a medullaris pajzsmirigyrák (MTC), mely egy neuroendokrin daganat, az összes pajzsmirigy-carcinoma 2-5\%-a. E típus a pajzsmirigyben található, de fejlődéstanilag nem onnan eredő, ún. parafollicularis C-sejtekból származik. A MTC kialakulásában a legjelentősebbek a RET-gén mutációi (több százról számoltak már be), ezenkívül számos egyéb $R A S$ - és TSHR-mutáció is érintett a kialakulásában.

2010-re munkacsoportunk kidolgozott egy 8 gén vizsgálatán alapuló panelt (4 szomatikus génmutáció: $B R A F, H R A S, N R A S, K R A S$ és 4 génátrendeződés: RET/PTC1, RET/PTC3, PAX8ex7/PPARgamma, PAX8ex9/PPARgamma), mely pajzsmirigyszöveti minták szomatikus mutációs mintázatának elemzését végzi Light Cycler leolvadásigörbe-analízissel [6]. Ezt a kezdeti génszettünket továbbfejlesztettük egy kiterjesztett, sokkal több gén vizsgálatát magában foglaló módszerrel, mely a legmodernebb molekuláris genetikai diagnosztikai eljáráson, az NGS-technikán alapul. A géndiagnosztikus panel megtervezése, kialakítása és ismert hisztopatológiai eredményű műtéti pajzsmirigyszövet-mintákon való validálási folyamata után célunk volt azt FNAB-mintákra is alkalmazhatóvá tenni, így kiegészítve a citológiai eredményeket.

Vizsgálatsorozatunk első felében irodalmi adatok alapján új, a legtöbb releváns gént magában foglaló panelt alakítottunk ki, mely az első és a legszélesebb körü Európában. Ezt követően módszerünket sikeresen alkalmaztuk FNAB-mintákon is, jó pozitív prediktív és szenzitivitási értékekkel. Kapott eredményeink a már jól ismert ún. driver génben, a BRAF-ban bekövetkező mutációk jelentőségét sikeresen megerősítették, míg a génpanelbe bevont egyéb gének elemzése is értékesnek mutatkozott.

Az LPRA4-gén szerepe a mai napig nem tisztázott, szomatikus mutációit különböző rosszindulatú daganatokban azonosították már (például vastagbélrák, a fej és nyak laphámsejtes carcinomája $[14,15])$, míg Pan és mtsai a PTC-ben mint létfontosságú onkogént detektálták [7]. Az APC-gén mutációi főként PTC-re jellemzők, de megfigyelték már ATC-ben is: egy japán populációt 
vizsgáló tanulmányban például a megvizsgált ATC-s páciensek 9\%-a hordozott az APC-génben mutációt [16], az általunk megtalált variánsát azonban eddig még nem írták le. Az AXIN1-gént a leginkább az ATC kialakulásával hozzák kapcsolatba [17], a talált MNV-t és a benignus állapotú citológiai mintákban felfedezett variánsokat (c.1887_1891delCCAGA és c.2155A>G) eddig még nem írták le a szakirodalomban. A $S M A D 4$ c.1569C>G variánsát 1 mintánkban fedeztük fel, melyet fooként vastagbélrákban jegyeznek [18]. A TSHR-génnek alapvető szerepe van a pajzsmirigysejtek proliferációjában, differenciálódásában [19], így mutációi daganat kialakulásához vezethetnek. A TSHR megtalált misszensz variánsai az irodalomban patogén besorolásúak [20-22], esetünkben 1-1 citológiailag negatív eredményü mintában voltak jelen. A TSHR másik 2 deletiós és 1 MNV variánsáról (3. táblázat) szakirodalomi adat még nem érhető el, elsőként azonosítottuk.

Két olyan pozitív citológiai eredményű páciensünk volt, akik esetében nem tudtunk detektálni eltérést egyik vizsgált génben sem; ennek több magyarázata is lehet. Egyrészt az alkalmazott NGS-rendszer technikai beállítása nem vagy csak limitáltan képes a génátrendeződések és nagy deletiók/insertiók vizsgálatára. Másrészt ismert, hogy a daganatok kialakulásában a génexpressziót érintő szabályozási hibák is állhatnak, melyek csak más módszerrel detektálhatók. Ezenkívül meg kell említeni, hogy bár napjainkig a fellelhető összes, pajzsmirigytumorral összefüggésben leírt, releváns gént beválogattuk panelünkbe, maradhattak még eddig fel nem tárt gének és variánsok.

A vizsgálat pillanatában citológiailag benignusnak ítélt göbök nagy részében ( 70\%) is találtunk valamilyen mutációt. Ezek közül 5 olyan mutációt azonosítottunk, melyeket már a szakirodalomban is a pajzsmirigy rosszindulatú daganatával hoztak összefüggésbe. Ezek közül a legismertebb a HRAS c.181C>A variánsa, mely PTC-s és FTC-s betegek mintáiban is gyakran előfordul [23]. A citológiailag jóindulatú mintákban a legtöbbször az $L P A R 4$ c.137A>G mutációja fordult elő, ami a fentebb említettek alapján a PTC-s állapottal van összefüggésben. Ezek alapján a megtalált mutációk megléte egy citológialag negatív mintában előre jelezheti a későbbi malignitás kialakulását. Ezen pácienseknél csak egyéni mérlegelés után - citológiai eredmény, UH-adatok, egyéb elvégzett vizsgálatok, illetve az NGS során kapott genetikai eredmények figyelembevételével - adhatunk ki szakorvosi véleményt a szóban forgó göb(ök)ről. Természetesen ezen betegek hosszú távú követése fontos előrejelzésünk pontosságának megítéléséhez.

A malignitásra gyanús, bizonytalan citológiájú minták több mint felében találtunk genetikai eltérést, melyek közül a driver onkogén BRAF c.1799T>A és NRAS c.181C>A előfordulása döntőnek bizonyult a végleges diagnózis kiadásakor, és mütéti beavatkozást javasoltunk. A többi mintánál az APC, AXIN1, LPAR4, SMAD4, TERT és $V H L$ génekben azonosítottunk mutációkat, mely esetekben a páciensek jóval szorosabb szakorvosi követése javasolt, és amennyiben az adott göb nagysága vagy ultrahangos jellege megváltozna, ismételt mérlegelés szükséges az esetleges mütéti beavatkozás szükségességéról. A negatív és bizonytalan citológiai eredményt mutató göbökben felfedezett mutációk sok esetben előrevetíthetik a rosszindulatú daganatok kialakulásának lehetőségét. Tehát a genetikai és a citológiai vizsgálat együttesen sokkal megbízhatóbb eredményt nyújthat.

A világban több külföldi cég is dolgozott már ki pajzsmirigyszövet vizsgálatára alkalmas géndiagnosztikai teszteket, melyek szenzitivitása és specificitása, illetve pozitív és negatív prediktív értéke közel hasonlónak mutatkozik az általunk kialakított paneléhez. A ThyGenX-et - amely PCR segítségével több száz ponton vizsgál nyolc gént (a BRAF, HRAS, NRAS, KRAS génmutációit és a RET/PTC1, RET/PTC3, PAX8/PPAR $\gamma$ génátrendeződéseit) - kiegészítették a ThyraMIR-rel (további tíz miRNS expressziójának elemzésével), így ezek együttes alkalmazásával elérték a 74\%-os PPV- és 94\%-os NPVértékeket [24]. Az Afirma panelnek (167 gén mRNSexpresszióját elemzi) szenzitivitási és NPV-értéke elég magas értéket ért el (92\%, illetve 94-95\%), PPV-je azonban igen alacsony (37\%) [25], így ha bizonytalan eredményt ad, akkor az adott esetnek továbbra sincs megbízható, végleges diagnózisa. A ThyroSeq v3-as, legújabb verziója DNS-t és RNS-t is vizsgál NGS segítségével, összesen 112 gént elemez. E teszt szenzitivitása 91-97\% között alakul, PPV-értéke 50-80\%, míg NPV-je 89100\% között mozog [26]. Európában először, az általunk kifejlesztett, 23 gént magában foglaló, pajzsmirigygöbből származó mintát vizsgáló panel a már meglévő tesztek értékeihez hasonló eredményeket mutat (szenzitivitás: 79\%, specificitás: 86\%, PPV: 89\%, NPV: 75\%), így megbízhatóan használható.

\section{Következtetés}

Elmondhatjuk, hogy egy olyan validált, FNAB-mintákon is megbízhatóan múködő NGS-alapú módszert fejlesztettünk ki, mely nemzetközi viszonylatban is megállja a helyét. A munkacsoportunk által kidolgozott géndiagnosztikai panel sikeres elvégzéséhez a legfontosabb a megfelelő mennyiségü kezdeti DNS, melyet a jól kivitelezett biopsziás mintavételezés biztosít. Molekuláris genetikai módszerünk segítséget nyújthat a klinikai döntéshozatalban, mely alkalmas a pajzsmirigy rosszindulatú elváltozásainak korai előrejelzésére.

Anyagi támogatás: A közlemény megírása, illetve a kapcsolódó kutatómunka anyagi támogatásban nem részesült.

Szerzői munkamegosztás: K.-D. B.: A szakirodalom kutatása, a kézirat összeállítása, laboratóriumi munkafolyamatok elvégzése, adatok elemzése. B. B.: Irodalom- 
kutatás, a kézirat összeállítása. Á. K.: Laboratóriumi munkafolyamatok elvégzése, adatok elemzése. T. B.: Irodalomkutatás, a kézirat összeállítása. Gy. G., J. B., Sz. E.: Mintavételezés. P. J.: Adatelemzés. K. J., L. P.: A kutatási téma megtervezése és a kézirat kritikus átolvasása. A cikk végleges változatát valamennyi szerző elolvasta és jóváhagyta.

Érdekeltségek: A szerzőknek nincsenek érdekeltségeik.

\section{Irodalom}

[1] National Cancer Institute. Cancer stat facts: thyroid cancer Available from: https://seer.cancer.gov/statfacts/html/thyro. html [accessed: September 12, 2017].

[2] Halászlaki C, Tóbiás B, Balla B, et al. Predictive value of somatic mutations for the development of malignancy in thyroid nodules by cytopathology. Endocr Pract. 2016; 22: 1081-1087.

[3] Lakatos P, Tóbiás B, Kósa J, et al. Molecular pathology of differentiated thyroid cancers: Where do we stand in 2016? [Differenciált pajzsmirigyrákok molekuláris diagnosztikája: Hol tartunk 2016-ban?] Magyar Belorv Arch. 2016; 69: 98-103. [Hungarian]

[4] Cibas ES, Ali SZ. The Bethesda system for reporting thyroid cytopathology. Thyroid 2009; 19: 1159-1165.

[5] D'Cruz AK, Vaish R, Vaidya A, et al. Molecular markers in welldifferentiated thyroid cancer. Eur Arch Otorhinolaryngol. 2018; 275: 1375-1384

[6] Tóbiás B, Halászlaki C, Balla B, et al. Genetic alterations in Hungarian patients with papillary thyroid cancer. Pathol Oncol Res. 2016; 22: 27-33.

[7] Pan W, Zhou L, Ge M, et al. Whole exome sequencing identifies IncRNA GAS8-ASI and LPAR4 as novel papillary thyroid carcinoma driver alternations. Hum Mol Genet. 2016; 25: 18751884.

[8] Kocsis-Deák B, Balla B, Tóbiás B, et al. Molecular genetic examinations in the diagnosis of thyroid tumors. [Molekuláris genetikai vizsgálatok a pajzsmirigy daganatainak diagnosztikájában.] Orvostovábbk Szle. 2018; 25: 49-53. [Hungarian]

[9] Carpi A, Mechanick JI, Saussez S, et al. Thyroid tumor marker genomics and proteomics: diagnostic and clinical implications. J Cell Physiol. 2010; 224: 612-619.

[10] Erinjeri NJ, Nicolson NG, Deyholos C, et al. Whole-exome sequencing identifies two discrete druggable signaling pathways in follicular thyroid cancer. J Am Coll Surg. 2018; 226: 950-959. e5.

[11] Zolotov S. Genetic testing in differentiated thyroid carcinoma: indications and clinical implications. Rambam Maimonides Med J. 2016; 7: e0009.

[12] Cancer Genome Atlas Research Network. Integrated genomic characterization of papillary thyroid carcinoma. Cell 2014; 159: 676-690.
[13] Xing M. Molecular pathogenesis and mechanisms of thyroid can cer. Nat Rev Cancer 2013; 13: 184-199.

[14] Harper K, Arsenault D, Boulay-Jean S, et al. Autotaxin promotes cancer invasion via the lysophosphatidic acid receptor 4: participation of the cyclic AMP/EPAC/Racl signaling pathway in invadopodia formation. Cancer Res. 2010; 70: 4634-4643.

[15] Matayoshi S, Chiba S, Lin Y, et al. Lysophosphatidic acid receptor 4 signaling potentially modulates malignant behavior in human head and neck squamous cell carcinoma cells. Int J Oncol. 2013; 42: 1560-1568.

[16] Kurihara T, Ikeda S, Ishizaki Y, et al. Immunohistochemical and sequencing analyses of the Wnt signaling components in Japanese anaplastic thyroid cancers. Thyroid 2004; 14: 1020-1029.

[17] Sykorova V, Dvorakova S, Vcelak J, et al. Search for new genetic biomarkers in poorly differentiated and anaplastic thyroid carcinomas using next generation sequencing. Anticancer Res. 2015; 35: 2029-2036.

[18] Péterfia B, Kalmér A, Patai AV, et al. Construction of a multiplex mutation hot spot PCR panel: the first step towards colorectal cancer genotyping on the GS Junior platform. J Cancer 2017; 8: $162-173$.

[19] Kimura T, Van Keymeulen A, Golstein J, et al. Regulation of thyroid cell proliferation by TSH and other factors: a critical evaluation of in vitro models. Endocr Rev. 2001; 22: 631-656.

[20] Gozu H, Avsar M, Bircan R, et al. Mutations in the thyrotropin receptor signal transduction pathway in the hyperfunctioning thyroid nodules from multinodular goiters: a study in the Turkish population. Endocr J. 2005; 52: 577-585.

[21] Tonacchera M, Chiovato L, Pinchera A, et al. Hyperfunctioning thyroid nodules in toxic multinodular goiter share activating thyrotropin receptor mutations with solitary toxic adenoma. J Clin Endocrinol Metab. 1998; 83: 492-498.

[22] Palos-Paz F, Perez-Guerra O, Cameselle-Teijeiro J, et al. Prevalence of mutations in TSHR, GNAS, PRKARIA and RAS genes in a large series of toxic thyroid adenomas from Galicia, an iodine-deficient area in NW Spain. Eur J Endocrinol. 2008; 159: 623-631.

[23] Pozdeyev N, Gay LM, Sokol ES, et al. Genetic analysis of 779 advanced differentiated and anaplastic thyroid cancers. Clin Cancer Res. 2018; 24: 3059-3068.

[24] Nishino M. Molecular cytopathology for thyroid nodules: a review of methodology and test performance. Cancer Cytopathol. 2016; 124: 14-27.

[25] Alexander EK, Schorr M, Klopper J, et al. Multicenter clinical experience with the Afirma gene expression classifier. J Clin Endocrinol Metab. 2014; 99: 119-125.

[26] Nikiforova MN, Mercurio S, Wald AI, et al. Analytical performance of the ThyroSeq v3 genomic classifier for cancer diagnosis in thyroid nodules. Cancer 2018; 124: 1682-1690.

(Kocsis-Deák Barbara, Budapest, Korányi S. u. 2/A, 1083 e-mail: kocsisd.barbi@gmail.com)

A cikk a Creative Commons Attribution 4.0 International License (https://creativecommons.org/licenses/by/4.0/) feltételei szerint publikált Open Access közlemény, melynek szellemében a cikk bármilyen médiumban szabadon felhasználható, megosztható és újraközölhetö, feltéve, hogy az eredeti szerző és a közlés helye, illetve a CC License linkje és az esetlegesen végrehajtott módositások feltüntetésre kerülnek. (SID_1) 